\title{
WestVirginiaUniversity
}

THE RESEARCH REPOSITORY @ WVU

Graduate Theses, Dissertations, and Problem Reports

2000

\section{Evaluation of the International 4-H Youth Exchange (IFYE) Program}

\author{
Mary Elizabeth Williams \\ West Virginia University
}

Follow this and additional works at: https://researchrepository.wvu.edu/etd

\section{Recommended Citation}

Williams, Mary Elizabeth, "Evaluation of the International 4-H Youth Exchange (IFYE) Program" (2000). Graduate Theses, Dissertations, and Problem Reports. 1061.

https://researchrepository.wvu.edu/etd/1061

This Thesis is protected by copyright and/or related rights. It has been brought to you by the The Research Repository @ WVU with permission from the rights-holder(s). You are free to use this Thesis in any way that is permitted by the copyright and related rights legislation that applies to your use. For other uses you must obtain permission from the rights-holder(s) directly, unless additional rights are indicated by a Creative Commons license in the record and/ or on the work itself. This Thesis has been accepted for inclusion in WVU Graduate Theses, Dissertations, and Problem Reports collection by an authorized administrator of The Research Repository @ WVU. For more information, please contact researchrepository@mail.wvu.edu. 
Evaluation of the International 4-H Youth Exchange (IFYE) Program

\author{
Mary Elizabeth Williams
}

Thesis submitted to the

College of Agriculture, Forestry, and Consumer Sciences

at West Virginia University in partial fulfillment of the requirements

for the degree of

\author{
Master of Science \\ in \\ Agricultural Education
}

Layle D. Lawrence, Ph.D., Chair

Stacy A. Gartin, Ph.D.

Dennis Smith, Ph.D.

Division of Resource Management

Morgantown, West Virginia

2000

Key Words: Exchange, 4-H, International, Youth, 


\section{ABSTRACT \\ Evaluation of the International 4-H Youth Exchange (IFYE) Program}

\section{Mary Elizabeth Williams}

The purpose of this study was to examine the extent to which the International 4-H Program achieved its objectives regarding positive cross-cultural attitudes, life leadership skills, and host culture knowledge through the six-month International 4-H Youth Exchange (IFYE) Program. The population consisted of the twenty-one 1999 IFYE six-month representatives. A descriptive census survey was used to collect the data for the study. Each participant completed pre- and post- exchange evaluations while attending the program orientation and debriefing at the National 4-H Center. The major finding of this study was the representative's significant gain in host culture knowledge. The IFYE representatives' positive cross-cultural attitudes and perceptions existed before their exchange experience. The experience, however, results in greater appreciation for the United States, strengthens awareness of world issues, improves communication skills, and overcomes misperceptions about the host country. Representatives did develop their life leadership skills yet, not to the extent originally expected. 
Dedicated to the Past, Present, and Future

International 4-H Youth Exchange Representatives 


\section{ACKNOWLEDGEMENTS}

I would like to express my appreciation to the 1999 six- month International 4-H Youth Exchange (IFYE) representatives who participated in this study. Without their participation and dedication to the IFYE program, this study would not have been successfully completed.

Appreciation is especially extended to the Director of CD International Program Services, L.L.C., Cecil Morrow, the National 4-H Program Leader, Virginia Gobeli, and the IFYE Alumni Association, and for allowing me to conduct the evaluations.

Special thanks to Dr. Layle D. Lawerence, who served as Academic Advisor and Chair of the Examining Committee, for his guidance, patience, and constructive suggestions in the preparation of this thesis.

Appreciation and thanks are expressed to Examining Committee member, Dr.

Stacy A. Gartin, for his advice, support, and sense of humor.

Sincere thanks to Dr. Dennis Smith, Examining Committee member, for his assistance, encouragement, and genuine concern and interest in all of his students.

Special thanks to Dr. Kerry Odell for taking the time to help me with my statistical analysis. I am grateful for the opportunity I had to work with you.

The writer wishes to express a very special thank you to her family and friends who have been a constant source of love, encouragement and continuous support throughout her college career. I could not have done this without you. Thank you. 


\section{TABLE OF CONTENTS}

TITLE PAGE i

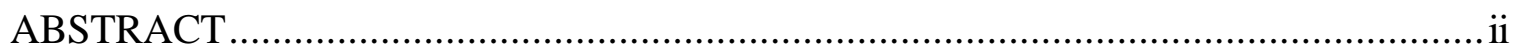

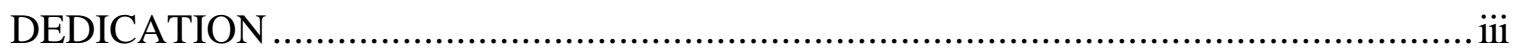

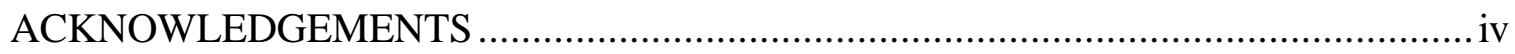

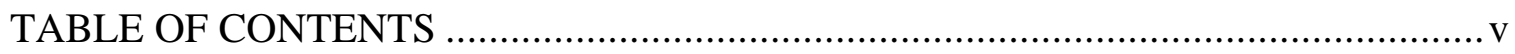

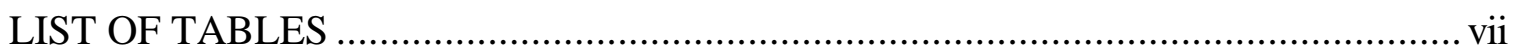

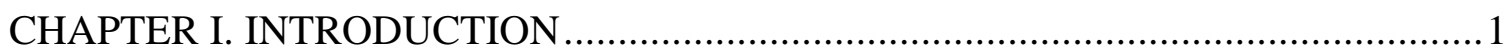

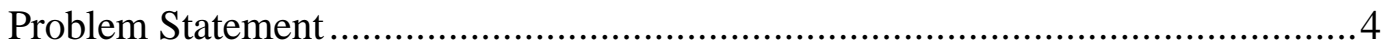

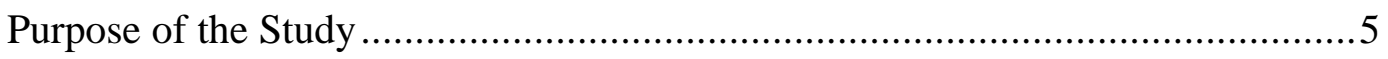

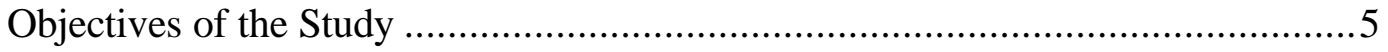

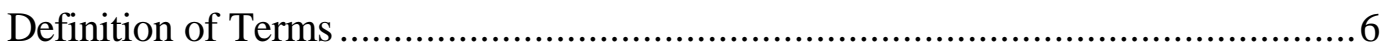

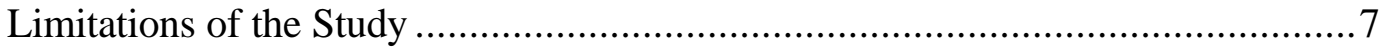

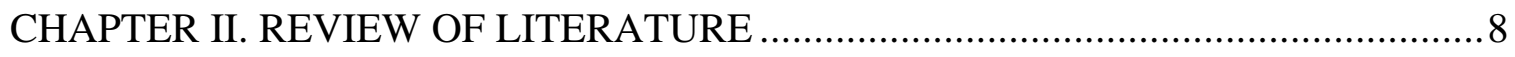

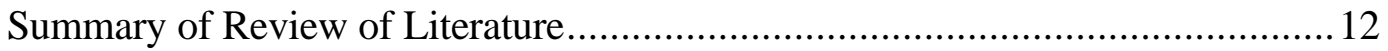

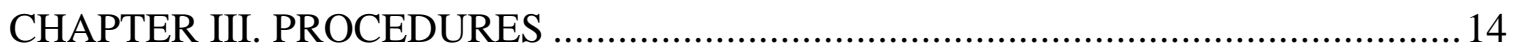

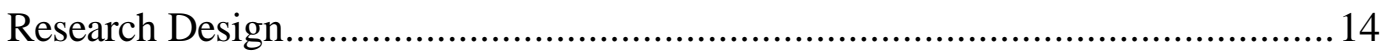

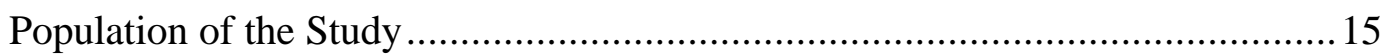

Instrumentation...........................................................

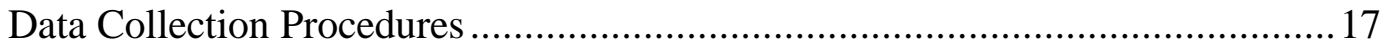

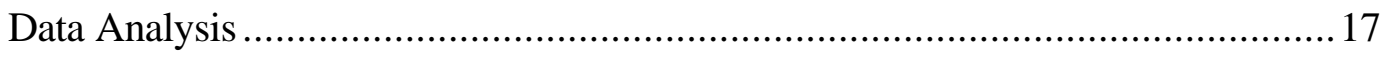

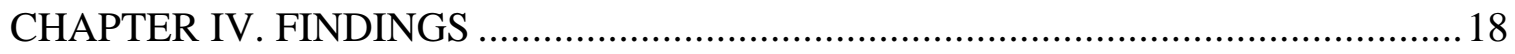

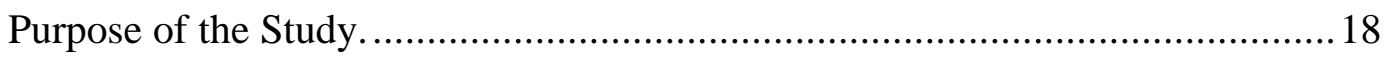

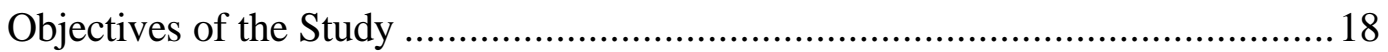


Demographic Characteristics of the 1999 Six-Month IFYE Representatives ....... 19

Demographic Characteristics of the 1999 Six-Month IFYE Representatives with Frequency and Percents ....................................................... 21

Cross-Cultural Attidues and Perceptions Developed ......................................22

Comparisons of Participants Attitudes and Perceptions Before and After the

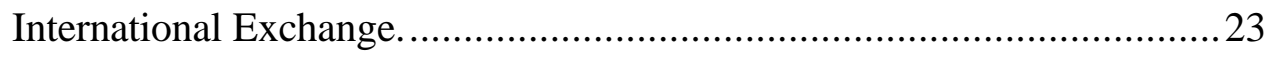

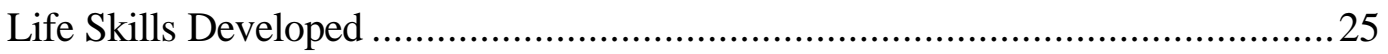

Comparisons of Participants' Expected (Before) and Actual (After) Level of

Life Skills Gained.........................................................................2 26

Participant's Knowledge of Host Culture............................................... 28

Comparison of Participants Knowledge of Host Culture Before and After the International Exchange......................................................... 29

CHAPTER V. SUMMARY, CONCLUSIONS AND RECOMMENDATIONS .............30

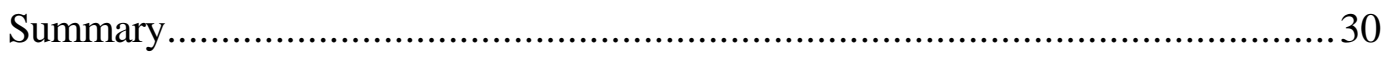

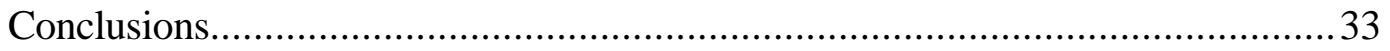

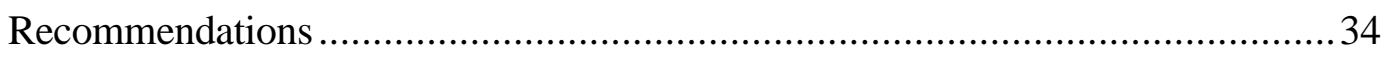

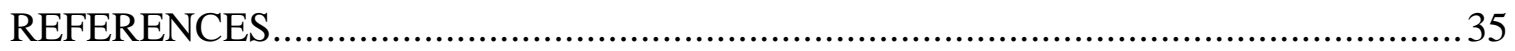

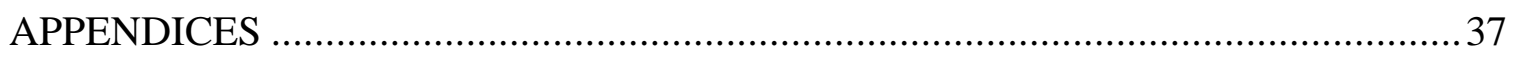

APPENDIX A: Cover Letter to the 1999 Six Month IFYE Representatives .......39

APPENDIX B: The International 4-H Youth Exchange (IFYE)

Evaluation 
APPENDIX C: The National Association of Extension 4-H Agents U.S.

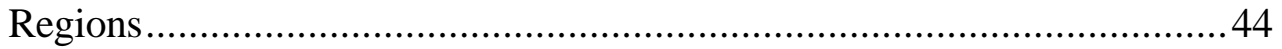

VITA 


\section{LIST OF TABLES}

1. Demographic Characteristics of the 1999 six-month IFYE Representative...............21

2. Comparisons of Participants Attitudes and Perceptions Before and After the IFYE Experience...............................................23

3. Comparisons of the Participants Expected (Before) and Actual (After) Gain of Life Skills........................................................26

4. Comparisons of Participants Knowledge of Host Culture Before and After the IFYE Exchange................................................29 


\section{CHAPTER I}

\section{INTRODUCTION}

International travel has long been viewed as one method of introducing a global perspective into the personal development of young people. Numerous programs currently exist which promote international youth exchange opportunities. One such program is the International 4-H Youth Exchange (IFYE), which originated as the International Farm Youth Exchange and was developed due to the need for increased international understanding that would contribute to lasting world peace (International 4-H Task Force Report, 1985). Starting in 1948, under the direction of the National 4-H Council 17 young adults, ages 19 to 25 went to live and work with host farm families for six months in a foreign country. The purpose for the 4-H exchange was for American youth to "learn by doing" by submerging themselves in a foreign culture, and to promote world peace. Due to the success of the six-month program, a short-term exchange (4-5 weeks) called IFYE Ambassador was later added. For approximately 50 years, these programs have sought to enhance the United States of America 4-H program through international, cross-cultural experiences that enable young people to improve their leadership and communication skills, while increasing their international awareness and understanding.

In 1992, the National 4-H Council could no longer justify supporting the IFYE program due to decreasing participation, and ended their administration of both IFYE programs. Faced with the likely termination of the IFYE programs, the International Four-H Youth Exchange Association of the USA (IFYE Association), in cooperation with Virginia Gobeli, the National 4-H Program Leader, agreed to continue the IFYE program (IFYE Handbook, 1999). The Extension Service- United States Department of 
Agriculture (ES-USDA) approved the proposal that the IFYE Association take over administration of the program from the National 4-H Council. A private group based in Phoenix, Arizona known as CD International Program Services, L.L.C., directed by two past IFYEs, was selected by the IFYE Association to manage the IFYE Program. Overall, the IFYE program functions on a cooperative basis with CD International Services, state and/or country IFYE Coordinators, State Extension Agents, and increasingly, IFYE Alumni. Interestingly, even though the administration of the IFYE program has changed the program's mission and objectives have remained the same.

The Extension Committee on Organization and Policy (ECOP) (1995) states the basic mission of Extension is to "enable people to improve their lives and communities through learning partnerships that put knowledge to work." One way the extension works to achieve the goal of establishing learning partnerships is through international exchange programs. According to the 1999 IFYE Handbook the mission of 4-H International Programs is to further cross-cultural understanding and international development through study and exchange of human and technical resources:

1. To assist 4-H youth, volunteers, 4-H alumni and their families in acquiring knowledge, developing life skills, and forming attitudes that will further their development as self-directed, productive members of an interdependent global community;

2. To support 4-H type, youth development, educational programs in other countries; and

3. To provide opportunities for youth (4-H and non 4-H) to know and interact with other individuals as human beings worthy of respect regardless of ethnic background, socio-economic status, sex, or age (p.33). 
The specific objectives of the 4-H International Program recommended in the Report of the International 4-H Task Force (1985) and currently stated in the IFYE Handbook (1999) are to assist youth and adults in the United States and other countries to:

1. Participate in the enrichment of the world's people through the exchange of ideas, philosophies, and technological practices, especially those which contribute to international development including increasing food production, improving nutrition, strengthening world trade and encouraging international career development.

2. Develop positive cross-cultural attitudes and skills that enhance mutual understanding and acceptance which contribute to world peace.

3. Learn more about other countries and cultures and develop an appreciation of the social, economic, political, and cultural contributions of all people.

4. Understand and assume their international citizenship responsibilities in today's interdependent world. (p. 33).

In order to complete these objectives, 4-H youth from across the world are selected yearly to participate in the exchange program. The international exchange experience may last up to four weeks if participating in the IFYE Ambassador program or three to six months if selected as an IFYE Representative. The participants are notified by CD International Program Services generally in February of their host country. The logistics of the exchange are organized by CD International, all other preparations such as, learning the host cultures' language and customs, are solely the responsibility of the individual participants. The representatives depart at the end of June after a four-day orientation at the National 4-H Center in Chevy Chase, MD. Upon their return in 
September or mid-December they attend a three-day debriefing also hosted at the National 4-H Center.

During the exchange the IFYE participant may stay with one or two host families, or possibly fifteen or twenty depending on the length of stay and the country visited. It is not uncommon for the participant to come in contact with several hundred people while on the exchange. When the participants return to their home state most are required to conduct at least five presentations about their experience. However, some states require the representative to visit each county in their state and give several presentations while they are there. If such is the case, it is not unusual for the participants to speak to several thousand people in their home state about their IFYE experience. In West Virginia for example, the representatives are required to spend approximately five months traveling to each of the state's 55 counties. They speak to groups of all ages, often ranging in size from 5 to 500 people. Over the period of five months the WV representative has the potential to speak to over 11,000 people about his or her IFYE experience. Fascinatingly, in just one U.S. state thousands of people are influenced yearly by the International 4-H Youth Exchange program, imagine the impact worldwide!

\section{Problem Statement}

Although the IFYE program has existed for over 50 years, is supported by several organizations, has solid objectives in place, and has affected the lives of thousands around the world, a formal evaluation of the program has yet to occur. Particularly within the cooperative extension system, evaluation has continually become more important as accountability becomes more crucial and financial support less available (ChapmanNovakofski et al., 1997). It is of primary importance that a program such as this be analyzed and evaluated in order to determine if the structure of the IFYE Program allows 
the participants to actually achieve the previously mentioned 4-H International Program objectives.

\section{Purpose of the Study}

The purpose of this study was to examine the extent to which the 4-H International Program achieves its objectives with regard to the six-month IFYE Program. The IFYE program which is managed by $\mathrm{CD}$ International in cooperation with the Cooperative Extension Service, and IFYE Alumni provides the opportunity for 4-H youth to travel abroad and live with host families from four weeks to six months with the goal of developing positive cross-cultural attitudes, skills, knowledge, understanding, and appreciation. The intent of this study is to determine if the objectives set by the program are actually being achieved by the 1999 six-month U.S. IFYE Representatives. It is important to note that due to the complexity of actually evaluating objectives 1 and 4 set by the 4-H International Program, the researcher chose to evaluate only objectives 2 and 3 which are listed on page three.

\section{Objectives of the Study}

The specific objectives of this study are:

1. To describe the participants in the 1999 six-month IFYE Program.

2. To determine if positive cross-cultural attitudes that enhance mutual understanding and acceptance developed during the IFYE experience.

3. To determine if positive cross- cultural life skills that enhance mutual understanding and acceptance were developed during the IFYE experience.

4. To assess the representatives' knowledge of their host country's social, economic, and political status, and cultural contributions. 


\section{Definition of Terms}

The following terms are important to the understanding of concepts discussed in this paper:

Cooperative Extension Service- is a public-funded, non-formal, educational system that links the education and research resources of the U. S. Department of Agriculture (USDA), land-grant universities, and county administrative units. The basic mission of this system is to help people improve their lives through an educational process that uses scientific knowledge focused on issues and needs (Seevers, Graham, Gamon, \& Conklin, 1997).

Host Family- Refers to a family that accepts the IFYE representative into their home as a family member for a set period of time (Boyd, 1971).

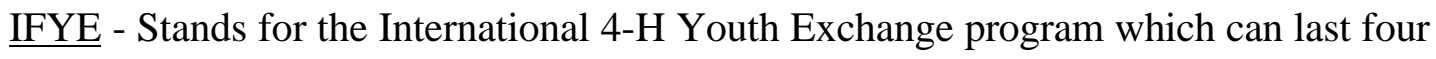
weeks, three months or six months depending on the participants' choice of exchange length.

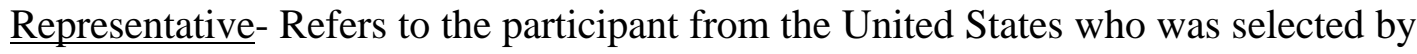
his/her home state to live in a foreign country for 4-5 weeks, three months or six months. Limitations of the Study

Several limitations exist within this study. It is important that these limitations are made clear at the beginning of this study so the reader will understand and appreciate the confines within which this study was conducted. The limitations are as follows:

1. The population used in the study is not representative of all 4-H youth across the United States therefore the results are limited to only those 4-H members who participated in the program.

2. The results of the study are limited to only those who participated in the 1999 
International 4-H Youth Exchange. 


\section{CHAPTER II}

\section{REVIEW OF LITERATURE}

The purpose of this study was to examine the extent to which the International 4-H Program achieves its objectives with regard to the six-month IFYE Program. Often foreign exchange programs organize all of the detailed aspects of the exchange, yet fail to analyze the outcome of their labor. Many programs have objectives they think the participants should have accomplished while on the exchange, but rarely is an evaluation conducted to determine if first, the objectives are realistic, and second, if they have actually been achieved.

Limited research has been conducted which involves the analysis of an international exchange program. In particular, the only study found relating specifically to the International 4-H Youth Exchange was An Analysis of the Role of the International Farm Youth Exchange Program in Cross-Cultural Communication (Boyd, 1971). However, several studies have been done concerning the impact or benefit of an international exchange (Hansel, 1984; Hansel, 1985; Kilby, 1993; Stitsworth and Yasushi, 1990; and Tritz and Martin, 1997). In 1983, with regard to 4-H international programs, the 4-H Subcommittee of ECOP appointed a 4-H International Programs Task Force to establish policy and procedural recommendations, to review existing policy, and to advise on the responsibilities of each faction involved. More recently, in 1998, a National 4-H Youth Development Global Education Design Team (1998) was formed to further develop program direction and objectives for the 4-H Youth Development Global Education policy.

The International Farm Youth Exchange (later changed to the International 4-H Youth Exchange) study conducted by Boyd (1971) focused on: (1) a description of the 
International Farm Youth Exchange (IFYE) program including its goals, function, organizational structure, operations and financial arrangements; (2) the concept of crosscultural communication and its implications for international understanding and world peace; and (3) an evaluation of the IFYE program in terms of its effectiveness in enhancing cross-cultural communication throughout the world. The results of the study indicated that the IFYE program does facilitate cross-cultural and interpersonal communications. However, the study did suggest three important weaknesses of the program: (1) inadequate language training, (2) lack of emphasis on human relation skills in the training program, and (3) a short length of time with the host family. Although this study has had a definite influence on the current study, it is crucial to note that the method used to collect the data in the Boyd (1971) study was library research and study only. Therefore, actual field data were not gathered as evidence of the effects of the IFYE program in cross-cultural communication.

The Hansel (1985) Impact of a Sojourn Abroad study examined the changes in 17 pre and post self-ratings of more than 1,000 youth who participated in the AFS International Intercultural Program in 1981. The author notes, "in this study, the AFS students showed significant increases in all 17 of these characteristics, but these increases were not always significantly greater than those shown by the AFS applicants who never traveled abroad [the Comparison Group]" (Hansel, 1985 p.127). The results of this study indicated it was not clear if the participants changed due to the exchange experience, or if they were simply growing up. The author recommended in order for this to be determined, very specific objectives must to be set before the exchange, and then evaluated at the end to determine if they have been achieved. 
The paper presented by Tritz and Martin (1997) suggests that although wonderful things do occur while traveling abroad, problems do arise. It is important to be aware of and prepared for something that was not planned, for example, health problems or theft. Tritz and Martin list 10 Criteria for a successful study abroad experience:

1. Set Goals- Realize your abilities, time-frame and set goals for what you want to accomplish.

2. Expectations- Be aware of your home and Host university's expectations

3. Focus Academic Pursuits- A much richer experience will be gained if your interests are focused.

4. Resources/Contacts- Take advantage of the resources both while in your home and host country.

5. Financial Management- Learn to budget; money matters when you're away for an extended period of time.

6. Culture Preparation- Learn customs and the do's and don't of the country you're going to be traveling to.

7. Identify Perceptions- Realize how you may be perceived and check-in with your own perceptions of the host country.

8. Language Training- If you're not fluent, learn some language. A working vocabulary is extremely helpful.

9. Communications- Realize we all communicate differently and that open communication is essential; both talking and listening.

10. An Open Mind- A positive attitude will only enhance your experience. Flexibility is the key. 
Although the IFYE program is not a study abroad program, all of these criteria could be easily modified to apply to the International 4-H Youth Exchange Program. Even though the objectives of the IFYE program are clearly stated, a means of accomplishing them could be beneficial. These ten criteria could be used to serve as an outline to help the IFYE representative meet the program objectives.

Due to an increase of interest, awareness, and activity in the 4-H international programs a 4-H subcommittee of ECOP, appointed a 4-H International Programs Task Force in June of 1983. The purpose of the Task Force was to:

1. Make policy and procedural recommendations concerning 4-H international programs to the 4-H subcommittee of ECOP.

2. Review existing policy related to the $4-\mathrm{H}$ international programs and assist in developing a plan to update that policy.

3. Advise on responsibilities of states, National 4-H Council, and the Extension Service related to current and future 4-H international programs (p.3).

The task force was allowed two years to complete the three tasks, and the final report was presented in January 1985. Of importance in relation to this study was the recommendation of the Task Force that a comprehensive impact study related to the 4-H international program be conducted (Rapking, 1985). It was suggested by the task force that two types of evaluations be conducted: an evaluation of the program results and an evaluation of the process and methodology. When evaluating the program results the report indicated the procedures to collect, evaluate, and report on the results that are necessary to document the far-reaching and long-term effects of personal exchanges in ways that record the visible and measurable benefits related to the program objectives. The report listed the following: 
1. Evaluate how participation affected the lives and attitudes of exchangees, host families, 4-H members, exchangees' families, and Extension staff related to:

a. Increased understanding of the United States' interdependence with other nations

b. Recognition of the values of 4-H type youth development programs

c. Knowledge of other people through living and working with them.

d. Exchange experience as a career path to an Extension, international, or other people-oriented career.

e. Cultural understanding and acceptance.

The five previously mentioned focus areas significantly aid in narrowing the scope of this study. Although this Task Force met well over ten years ago, no real evaluation of the program has occurred. Recently, another "task force" or team, The National 4-H Youth Development Global Education Design Team met with the intention of again developing appropriate objectives for $4-\mathrm{H}$ global education. Similar to the previous task force recommendations, this team stated one of the concerns of International $4-\mathrm{H}$ is to

“ Review, evaluate, and restructure exchange programs that meet the needs of youth and adults today, into the $21^{\text {st }}$ Century, and beyond" (Gobeli, 1998, p.3).

\section{$\underline{\text { Summary of Review of Literature }}$}

Evaluating international exchange programs has clearly been an ongoing concern, yet very few effective evaluations if any, have actually been conducted. It is apparent in order for such an evaluation to occur, specific objectives must be set in advance in order to eliminate the possibility of the change occurring as a result of the participant simply growing up and not the actual exchange experience. The trend in the Cooperative Extension Service is to conduct evaluations, but time and money are often limiting factors. 
However, if evaluations are not conducted, financial support is likely to become less available due to the sponsors not seeing solid benefits of the program. Evaluating the IFYE Program is important not only in determining if the objectives are attainable, but also in deciding if the objectives themselves are realistic. How long will these task force and teams continue to meet only to come to the same conclusions? It is time for the evaluations to begin! 


\section{CHAPTER III}

\section{PROCEDURES}

The purpose of this study was to examine the extent to which the International 4-H Program achieves its objectives with regard to the six-month U.S. International 4-H Youth Exchange (IFYE) program. This was conducted by administering a pre- and postevaluation to the 1999 U.S. IFYE representatives before and after their international exchange experience. This chapter seeks to explain the research methodology that were employed in order to accomplish the study. In the following sections the population, instrumentation, data collection method, and the data analysis techniques will be presented.

\section{Research Design}

A descriptive census survey was used to collect the data for this study. Ary, Jacob, and Razavick (1996) define descriptive research as those studies which “... ask questions about the nature, incidence, or distribution of variables; it involves description but not manipulation of variables" (p. 566). Descriptive research is relatively easy to conduct and a wide scope of information can be collected from the population using this type of methodology. A census survey refers to a survey that includes the entire population of interest. Instruments such as questionnaires and interviews are used in survey research to gather information from the group being studied. Surveys allow the researcher to analyze the characteristics of different groups or to measure their attitudes and opinions towards a certain issue (Ary, Jacob, and Razavick, 1996). Weaknesses are encountered when descriptive research includes the inability to make cause-effect or predictive statements, and the limitation of exploratory and descriptive statements. 


\section{Population of the Study}

The subjects in the study were the 1999 International 4-H Youth Exchange Representatives from the United States. These participants were chosen during the winter of 1999, generally after an interview process, by their home state as representative's to a foreign country for six months during the summer and fall of 1999. Final approval, and host country selection is determined by CD International, who contacted the representatives in the early spring 1999 to tell them their assigned host countries. Twentyone representatives participated in the 1999 six-month IFYE program. All of the participants in the IFYE program met at the National 4-H Center in Chevy Chase, MD at the end of June 1999 for several days of orientation. During this time the 21 participants were given the pre-evaluation survey. After the exchange was completed all of the participants assembled again at the National 4-H Center for several days during the middle of December 1999. During this time the post-evaluation survey was given to all 21 of the exchange representatives. All of the participants in the program completed both the preand post-evaluation, therefore, no random assignment or sampling of the population was need.

Instrumentation

Data for the study were obtained through pre- and post-evaluations administered to the participants directly before and after the exchange. The first section of the IFYE evaluation regarding attitudes was created by modifying a previously developed questionnaire by Hansel (1987). The reliability analysis of this section resulted in a Cronbach's Alpha coefficient of .73.

The second section of the evaluation which addresses leadership life skills was adapted from The Iowa FFA Youth Leadership Life Skills Development Questionnaire 
designed by Wingenbach (1995). The original Youth Leadership and Life Skills

Development Scale (YLLSDS) was developed by Seevers, Dormody, and Clason (1995).

Originally, after successfully being analyzed for face and content validity, the YLLSDS

was refined to 30 indicators of youth leadership and life skills development. The 30

indicators include: two communication skills, five decision making skills, seven skills in

getting along with others, four learning skills, three management skills, six skills in

understanding self, and three skills in working with groups (Wingenbach, 1995). Five

additional skills were added by the researcher to assess cross-cultural life skills. The

modified YLLSDS used in this study was assessed for reliability, which resulted in a

Cronbach's Alpha coefficient of 0.94 .

The third component of the evaluation which addressed host culture knowledge was developed by the researcher. The content validity of the overall evaluation was assessed by three Agricultural and Environmental Education faculty members and one member of the Agricultural and Resource Economics faculty at West Virginia University.

The IFYE evaluation was composed of four major sections. Section I consisted of 30 statements relating to the participants' ratings of his/her cross-cultural attitudes and perceptions. A four point Likert-type scale was used to describe both attitudes and perceptions of participant, with regard to their level of agreement or disagreement with each of the statements. Section II included 35 statements, also based on a four-point Likert-type scale, regarding the participants' level of gain pertaining to life skills. Section III contained 15 questions, which assessed the representatives' knowledge of their host culture with emphasis on social, economic, and political information, e.g., the respondents were asked to indicate the population, main form of government, main exports, average education level and average household income level of their host countries. Section IV of 
the evaluation requested demographic information, including home state, gender, age, martial status, and education level. For ease of reporting, home states were further organized by the researcher into regions established by the National Association of Extension 4-H Agents (NAE4-HA) (APPENDIX D). The regions are Northeast, North Central, South, and West.

\section{$\underline{\text { Data Collection Procedures }}$}

The data were collected using a census survey technique. All of the 1999 U.S. IFYE representatives were given pre- and post-evaluations by the researcher. The preevaluation was given during the orientation at the end of June at the National 4-H Center in Chevy Chase, MD. The post-evaluation was administered at the debriefing in the middle of December after all of the participants had returned from their host countries. The preand post- evaluations were given during the same time of day, with the same instructions. The same evaluation instrument was used during the pre-evaluation and the postevaluation.

\section{$\underline{\text { Data Analysis }}$}

This study sought to compare the 1999 IFYE representative's pre- and postexchange experience, cross-cultural attitudes and perceptions, life skills, and knowledge of their host country. Data obtained were analyzed at West Virginia University using the Statistical Package for Social Sciences for Windows (SPSS). Descriptive analyses were performed on the data in the form of paired sample t-tests, means, frequencies, and percentages. Levels of significance were set a priori at $\mathrm{p}<0.05$ for all statistical tests.

Based on standard deviations and means, data were recorded and reported in tabular form. A descriptive narrative was used in combination with the tabulated figures to explain the findings. 


\section{CHAPTER IV}

\section{FINDINGS}

The purpose of this study was to examine the extent to which the International 4-H Program achieved its objectives with regard to the 1999 six-month IFYE Program. The IFYE program managed by CD International in cooperation with the Cooperative Extension Service, provides the opportunity for 4-H youth to travel abroad and live with host families from four weeks to six months with the goal of developing cross-cultural attitudes, skills, knowledge and understanding. To accomplish this study's purpose, the 21 six-month IFYE representatives of 1999 completed pre- and post- evaluations regarding their cross cultural attitudes and perceptions, life skills, and host county knowledge.

The specific objectives of this study were:

1. To describe the participants in the 1999 six-month IFYE Program.

2. To determine if positive cross-cultural attitudes that enhance mutual understanding and acceptance developed during the IFYE experience.

3. To determine if positive cross-cultural life skills that enhance mutual understanding and acceptance were developed during the IFYE experience.

4. To assess the representative's knowledge of their host countries social, economic, and political status, and cultural contributions.

The data were collected during the IFYE program orientation in June, 1999 and the debriefing in December, 1999 at the National 4-H Center in Chevy Chase, MD. The survey instrument consisted of four sections. The first section obtained a measure of the participant's attitudes and perceptions relating to different cultures. The second section measured the level of life skills with regard to expected gain and actual gain. The third section evaluated the knowledge level of the participants concerning their host culture. 
The final section, gathered demographic information concerning the 1999 six month IFYE participants.

The responses of the complete research study population $(\mathrm{N}=21)$ of the 1999 IFYE representatives are summarized in the following pages. The results of the data are presented in the following areas: demographics; mean responses and t-test rating for comparisons of attitudes, life skills and general knowledge. Data obtained were analyzed at West Virginia University using the Statistical Package for Social Sciences for Windows (SPSS). Descriptive analyses were performed on the data in the form of paired sampled ttests, correlations, frequencies, and percentages. Based on standard deviations and means, data were recorded and reported in tabular form. Levels of significance were set a priori at $\mathrm{p}<0.05$ for all statistical tests.

\section{Demographic Characteristics}

Data were collected related to gender, age, home state, years in 4-H, martial status, level of education, traveling experience, and program recommendation. The analyses were based on 21 returned evaluations that represented a $100 \%$ response from the population.

As Table 1 illustrates, seven of the 1999 IFYE representatives were male and 14 were female. Their ages ranged from 18 to 26 years, with a mean of 21.24 years. For ease of reporting, home states were further organized by the researcher into regions established by the National Association of Extension 4-H Agents (NAE4-HA) (Figure 1). The regions are Northeast, North Central, South, and West. The majority of the participants, 11, were from the North Central region, 6 came from the Western region, 4 from the Northeast, and the Southern region had no participants. The participants' years in 4-H ranged from 0 to 16 , with a mean of 9.81 years. All of the participants were single. The 
highest level of education completed ranged from high school senior (12 years) to Master's degree (18 years) with a mean of 14.3 years of school completed. One respondent replied "Other" and did not indicate what "Other" meant and therefore was not calculated in the previously noted mean. Seventeen of the participants had previously traveled outside of the United States. Ten of the 17 had traveled for 1-15 days out of the U.S., three for 16-30 days, one for 31-45 days, and three had traveled more than 60 days outside of the U.S. Six of the 1999 IFYE participants or their families had hosted IFYE participants previous to their exchange. All of the representatives replied they would recommend the IFYE program to other 4-H members. The figures in Table 1 are based on the responses given on the pre-evaluation survey. 
Table 1.

Demographic Characteristics of the 1999 Six-Month IFYE Representatives.

\begin{tabular}{l}
\hline Variable \\
\hline Gender: \\
Male \\
Female \\
Age: \\
$18-20$ \\
$21-23$ \\
$24-26$
\end{tabular}

$\begin{array}{cc}\text { Frequency } & \text { Percent } \\ 7 & 33.3 \\ 14 & 66.7\end{array}$

Home region:

Northeast

North Central

South

West

$\begin{array}{cc}11 & 52.4 \\ 6 & 28.6 \\ 4 & 19.0\end{array}$

Years in 4-H:

$0-3$
$4-7$
$8-11$
$12-16$

$4 \quad 19.0$

$11 \quad 52.4$

$0 \quad 0.0$

628.6

artial status:

Single

Married

Divorced

$\begin{array}{ll}2 & 9.0\end{array}$

$\begin{array}{ll}0 & 0.0\end{array}$

$14 \quad 67.0$

$5 \quad 24.0$

Level of education:

H.S. Degree

A.A. Degree

B.A./B.S. Degree

M.S. Degree

Other

$21 \quad 100.0$

$\begin{array}{ll}0 & 0.0\end{array}$

$\begin{array}{ll}0 & 0.0\end{array}$

Have traveled outside of U.S. before: $\quad 17 \quad 81.0$

Yes

No

$4 \quad 19.0$

Davs traveled outside of U.S.:

$\begin{array}{ccc}0 & 4 & 19.0 \\ 01-15 & 10 & 48.0 \\ 16-30 & 3 & 14.0 \\ 31-45 & 1 & 5.0 \\ 46-60 & 0 & 0.0 \\ 60+ & 3 & 14.0\end{array}$

Have hosted an IFYE previously:

Yes

$6 \quad 29.0$

No

$15 \quad 71.0$

Recommend IFYE program to other 4-Hers:

Yes

$21 \quad 100.0$

No

$\begin{array}{ll}0 & 0.0\end{array}$




\section{Cross-cultural Attitudes and Perceptions Developed}

The data in Table 2 identify the overall mean rating, standard deviation and tvalue of the participants' attitudes and perceptions both before and after their six-month international exchange experience. The ratings fall into the four following categories: $1=$ "Strongly Disagree" $2=$ "Disagree", $3=$ "Agree", and $4=$ "Strongly Agree". Of the

30 statements rated by the representatives regarding attitudes and/or perceptions, eight of them showed significant change. The perception showing the most development involved the participants' view of their own knowledge of their host country. The average mean before the exchange was 2.48 and the average mean after was 3.43, a significant difference. The attitude showing the highest level of change related to one's belief that citizens in other countries wished they lived in the U.S. The difference in ratings for these statements was also significant. Before the exchange the mean was 2.05 and after the exchange the mean was 2.52. Additional statements in which significant differences were found concerned the need to know a foreign language (means of 1.43 and 1.76); if a program such as IFYE helps to develop positive communication skills (means of 3.43 and 3.86); perceptions of the importance of religion in their host country (means of 2.81 and 2.24); attitudes related to the U.S. being the best country to live in (means of 1.90 and 2.33); that the citizens of ones' host country generally like Americans (means of 2.81 and 3.19); and the importance of knowing about world issues (means of 3.81 and 4.00). The low standard deviations shown in Table 2 imply the closer agreement in participants' ratings. The negative t-values indicate a reversal in the direction from what the respondents' had originally responded. 
Table 2.

Comparisons of Participants Attitudes and Perceptions Before and After the International Exchange.

\begin{tabular}{|c|c|c|c|c|c|}
\hline \multirow[b]{2}{*}{ Statements Rated } & \multicolumn{2}{|c|}{ Before } & \multicolumn{2}{|c|}{ After } & \multirow[t]{2}{*}{$\underline{\mathrm{t}-\text { Value }}$} \\
\hline & $\underline{\mathrm{M}}$ & $\underline{\mathrm{SD}}$ & $\underline{\mathrm{M}}$ & $\underline{\mathrm{SD}}$ & \\
\hline It is important to know about world issues. & 3.81 & 0.40 & 4.00 & 0.00 & $2.17 *$ \\
\hline $\begin{array}{l}\text { An international youth exchange program } \\
\text { such as IFYE helps promote cultural } \\
\text { attitudes. }\end{array}$ & 3.86 & 0.36 & 3.95 & 0.22 & 1.45 \\
\hline $\begin{array}{l}\text { An international youth exchange program } \\
\text { such as IFYE helps develop positive } \\
\text { communication skills. }\end{array}$ & 3.43 & 0.75 & 3.86 & 0.36 & $2.63 *$ \\
\hline $\begin{array}{l}\text { I am very knowledgeable about the culture } \\
\text { of my host country. }\end{array}$ & 2.48 & 0.60 & 3.43 & 0.59 & $5.05 *$ \\
\hline $\begin{array}{l}\text { People in my host country believe education is } \\
\text { important. }\end{array}$ & 3.48 & 0.75 & 3.43 & 0.60 & -0.27 \\
\hline $\begin{array}{l}\text { The citizens from my host country have } \\
\text { strong family values (i.e. the nuclear family } \\
\text { unit is important). }\end{array}$ & 3.09 & 0.62 & 3.38 & 0.80 & 1.37 \\
\hline $\begin{array}{l}\text { It is important to be able to speak a foreign } \\
\text { language. }\end{array}$ & 3.19 & 0.51 & 3.29 & 0.46 & 1.00 \\
\hline $\begin{array}{l}\text { People in my host country are supportive of } \\
\text { their government. }\end{array}$ & 3.14 & 0.48 & 3.19 & 0.75 & 0.30 \\
\hline $\begin{array}{l}\text { It is important to be able to read a foreign } \\
\text { language. }\end{array}$ & 3.14 & 0.57 & 3.19 & 0.40 & 0.44 \\
\hline Citizens in my host country like Americans. & 2.81 & 0.60 & 3.19 & 0.60 & $2.36^{*}$ \\
\hline $\begin{array}{l}\text { Personal hygiene is important to the people } \\
\text { from my host country. }\end{array}$ & 3.00 & 0.45 & 3.00 & 0.63 & 0.00 \\
\hline $\begin{array}{l}\text { The dress habits of the people from my host } \\
\text { country are similar to the dress habits of } \\
\text { U.S. citizens. }\end{array}$ & 2.95 & 0.38 & 2.95 & 0.74 & 0.00 \\
\hline $\begin{array}{l}\text { The United States government should take ca } \\
\text { of its own problems first, before helping } \\
\text { other countries. }\end{array}$ & 2.43 & 0.60 & 2.62 & 0.59 & 1.07 \\
\hline $\begin{array}{l}\text { People from other cultures are not very } \\
\text { different from me. }\end{array}$ & 2.52 & 0.68 & 2.62 & 0.86 & 0.49 \\
\hline $\begin{array}{l}\text { The eating habits of the people in my host } \\
\text { country are similar to the eating habits of } \\
\text { U.S. citizens. }\end{array}$ & 2.81 & 0.59 & 2.57 & 0.75 & 1.16 \\
\hline
\end{tabular}

Note. * Indicates t-Value significance at 0.05 level of confidence $(\mathrm{DF}=20)$.

Rating Scale: 1= Strongly Disagree; 2= Disagree; 3= Agree; 4= Strongly Agree. 
Table 2 Continued.

\begin{tabular}{|c|c|c|c|c|c|}
\hline \multirow[b]{2}{*}{ Statements Rated } & \multicolumn{2}{|c|}{ Before } & \multicolumn{2}{|c|}{ After } & \multirow{2}{*}{$\begin{array}{c}\mathrm{t}- \\
\text { Value } \\
\end{array}$} \\
\hline & $\underline{\mathrm{M}}$ & $\underline{S D}$ & $\underline{\mathrm{M}}$ & $\underline{S D}$ & \\
\hline $\begin{array}{l}\text { The U.S. government system is better than } \\
\text { the type of government in my host country. }\end{array}$ & 2.38 & 0.67 & 2.52 & 0.68 & 0.83 \\
\hline $\begin{array}{l}\text { The citizens in other countries wish they } \\
\text { lived in the United States. }\end{array}$ & 2.05 & 0.80 & 2.52 & 0.87 & $2.91^{*}$ \\
\hline $\begin{array}{l}\text { The holidays in my host country are similar to } \\
\text { U. S. holidays. }\end{array}$ & 2.67 & 0.58 & 2.48 & 0.68 & -1.45 \\
\hline $\begin{array}{l}\text { All U.S. college aged citizens should be required } \\
\text { to participate in an international exchange } \\
\text { program. }\end{array}$ & 2.43 & 0.75 & 2.38 & 1.02 & -0.25 \\
\hline $\begin{array}{l}\text { The United States is the best country in the } \\
\text { world to live in. }\end{array}$ & 1.90 & 0.77 & 2.33 & 0.86 & $2.42^{*}$ \\
\hline $\begin{array}{l}\text { The customs in my host country are similar } \\
\text { to U.S. customs. }\end{array}$ & 2.23 & 0.54 & 2.24 & 0.62 & 0.00 \\
\hline $\begin{array}{l}\text { Religion is currently an important part of my } \\
\text { host country's culture. }\end{array}$ & 2.81 & 0.68 & 2.24 & 0.89 & $-2.55^{*}$ \\
\hline $\begin{array}{l}\text { The education system in my host country is } \\
\text { superior to the U.S. education system. }\end{array}$ & 2.29 & 0.78 & 2.19 & 0.87 & -0.49 \\
\hline $\begin{array}{l}\text { American food is better than food available in } \\
\text { my host country. }\end{array}$ & 2.05 & 0.67 & 2.14 & 0.79 & 0.62 \\
\hline $\begin{array}{l}\text { U. S. citizens are superior in knowledge } \\
\text { compared to the citizens from my host } \\
\text { country. }\end{array}$ & 1.81 & 0.68 & 1.95 & 0.49 & 1.00 \\
\hline $\begin{array}{l}\text { The government system in the United States } \\
\text { is better than all other forms of government. }\end{array}$ & 1.86 & 0.79 & 1.90 & 0.77 & 0.57 \\
\hline $\begin{array}{l}\text { Countries should not financially assist other } \\
\text { countries that are in need. }\end{array}$ & 1.81 & 0.60 & 1.86 & 0.57 & 0.33 \\
\hline $\begin{array}{l}\text { The education system in the United States is } \\
\text { superior to all other forms of education } \\
\text { systems. }\end{array}$ & 1.81 & 0.68 & 1.86 & 0.57 & 0.37 \\
\hline $\begin{array}{l}\text { There is no need to learn a foreign language } \\
\text { because most people understand English. }\end{array}$ & 1.43 & 0.51 & 1.76 & 0.62 & $2.65^{*}$ \\
\hline $\begin{array}{l}\text { The media coverage of world issues is all I } \\
\text { need to know about other cultures. }\end{array}$ & 1.52 & 0.75 & 1.33 & 0.58 & -1.07 \\
\hline
\end{tabular}

Note.* Indicates t-Value significance at 0.05 level of confidence $(\mathrm{DF}=20)$.

Rating Scale: $1=$ Strongly Disagree; $2=$ Disagree; $3=$ Agree; $4=$ Strongly Agree. 


\section{$\underline{\text { Life Skills Developed }}$}

Illustrated in Table 3 are comparisons of the participant's expected (before the exchange) and actual (after the exchange) level of Life Skills developed as a result of their IFYE exchange experience. The rating scale was as follows: $0=$ "No Gain ", $1=$ "Slight Gain", 2 = "Moderate Gain", and 3 = "A lot of Gain". The top ten Life Skills in which the participants indicated the most growth after the exchange were: flexibility (mean $=2.67$ ); being open to change $($ mean $=2.57)$; patience $($ mean $=2.48)$; open-mindedness $($ mean $=$ 2.48 ); being able to handle mistakes (mean $=2.48$ ); improvement of foreign language skill $($ mean $=2.33)$; friendly personality $($ mean $=2.29)$; clarification of values $($ mean $=2.24)$; selecting alternatives (mean $=2.24)$; and tying for tenth place were listening effectively, getting along with others, and being sensitive to others (mean $=2.19$ ).

Of the 35 statements listed involving Life Skills, 6 indicated significant change in the participant's belief of what skills they would develop as a result of their exchange experience. Interestingly, with regard to five of these significant statements, the participants' responded they gained less of these skills than they had anticipated. Only one statement, "selecting alternatives", indicated the participants gained more of this skill than they had originally expected (means of 1.86 and 2.24). The statements showing the largest negative t- values, or the skills they developed less than they had expected were: 1) Improving foreign language skill, 2) Improving ability to read a foreign language, 3) Setting goals, 4) Delegating responsibility, and 5) Creating an atmosphere of acceptance. The negative t- values indicate a reversal in the direction from which the respondents had originally responded. The high standard deviations shown in Table 3 imply the agreement in participants' ratings were not extremely similar. 
Table 3.

Comparisons of Participants' Expected (Before) and Actual (After) Level of Life Skills Gained.

\begin{tabular}{|c|c|c|c|c|c|}
\hline Statements Rated & \multicolumn{2}{|c|}{ Before } & \multicolumn{2}{|c|}{ After } & \multirow[b]{2}{*}{ t-Value } \\
\hline $\begin{array}{l}\text { (After) As a result of my IFYE experience I } \\
\text { am able to: }\end{array}$ & $\underline{\mathrm{M}}$ & $\underline{\mathrm{SD}}$ & $\underline{\mathrm{M}}$ & $\underline{\mathrm{SD}}$ & \\
\hline 1. Be flexible & 2.67 & 0.66 & 2.67 & 0.58 & 0.00 \\
\hline 2. Be open to change & 2.62 & 0.67 & 2.57 & 0.60 & -0.27 \\
\hline 3. Be open-minded & 2.52 & 0.68 & 2.48 & 0.68 & -0.24 \\
\hline 4. Handle mistakes & 2.10 & 0.62 & 2.48 & 0.68 & 1.90 \\
\hline 5. Be patient & 2.38 & 0.74 & 2.48 & 0.75 & 0.62 \\
\hline 6. Improve foreign language skill & 2.95 & 0.22 & 2.33 & 0.66 & $-4.24 *$ \\
\hline 7. Have a friendly personality & 2.29 & 0.78 & 2.29 & 0.90 & 0.00 \\
\hline 8. Select alternatives & 1.86 & 0.65 & 2.24 & 0.70 & $2.36 *$ \\
\hline 9. Clarify my values & 2.33 & 0.73 & 2.24 & 0.70 & -0.40 \\
\hline 10. Be sensitive to others & 2.43 & 0.75 & 2.19 & 0.87 & -1.23 \\
\hline 11. Listen effectively & 2.38 & 0.80 & 2.19 & 0.75 & -1.00 \\
\hline 12. Get along with others & 2.62 & 0.74 & 2.19 & 0.81 & -1.83 \\
\hline 13. Consider alternatives & 2.05 & 0.59 & 2.14 & 0.65 & 0.49 \\
\hline 14. Recognize the worth of others & 2.52 & 0.68 & 2.14 & 1.01 & -1.63 \\
\hline 15. Consider the needs of others & 2.29 & 0.84 & 2.10 & 0.70 & -0.81 \\
\hline 16. Improve self-esteem & 1.90 & 0.89 & 2.09 & 0.89 & 0.75 \\
\hline 17. Solve problems & 2.29 & 0.64 & 2.05 & 0.80 & -1.16 \\
\hline 18. Trust other people & 2.19 & 0.75 & 2.05 & 0.92 & -0.57 \\
\hline 19. Show a responsible attitude & 2.19 & 0.75 & 2.00 & 1.05 & -0.70 \\
\hline 20. Value others opinions & 2.48 & 0.75 & 2.00 & 0.95 & -1.90 \\
\hline 21. Use information to solve problems & 2.19 & 0.68 & 1.95 & 1.02 & -0.90 \\
\hline 22. Set priorities & 2.29 & 0.71 & 1.95 & 0.86 & -1.67 \\
\hline 23. Use rational thinking & 1.90 & 0.70 & 1.90 & 0.94 & 0.00 \\
\hline 24. Have a positive self-concept & 1.95 & 0.74 & 1.86 & 0.91 & -0.38 \\
\hline 25. Be respectful & 2.38 & 0.74 & 1.86 & 0.96 & -1.80 \\
\hline
\end{tabular}

Note. ${ }^{*}$ Indicates t-Value significance at 0.05 level of confidence $(\mathrm{DF}=20)$.

Rating Scale: 0= No Gain; 1=Slight Gain; 2= Moderate Gain; 3= A Lot of Gain. 
Table 3. Continued.

\begin{tabular}{|c|c|c|c|c|c|}
\hline Statements Rated & \multicolumn{2}{|c|}{ Before } & \multicolumn{2}{|c|}{ After } & \\
\hline $\begin{array}{l}\text { (Before) As a result of my IFYE experience I } \\
\text { expect to be able to: } \\
\text { (After) As a result of my IFYE experience I am } \\
\text { able to: }\end{array}$ & $\underline{\mathrm{M}}$ & $\underline{\text { SD }}$ & $\underline{\mathrm{M}}$ & $\underline{\mathrm{SD}}$ & $\underline{t-V a l u e}$ \\
\hline 26. Improve ability to read a foreign language & 2.71 & 0.56 & 1.86 & 0.96 & $-4.95^{*}$ \\
\hline 27. Create an atmosphere of acceptance in groups & 2.43 & 0.75 & 1.81 & 0.93 & $-2.21 *$ \\
\hline 28. Be tactful & 2.14 & 0.65 & 1.81 & 0.93 & -1.20 \\
\hline 29. Determine needs & 1.95 & 0.74 & 1.81 & 0.75 & -0.77 \\
\hline 30. Consider input from all group members & 1.90 & 0.94 & 1.76 & 0.89 & -0.70 \\
\hline 31. Have good manners & 1.95 & 0.74 & 1.71 & 0.78 & -1.04 \\
\hline 32. Set goals & 2.14 & 0.73 & 1.67 & 0.86 & $-2.91 *$ \\
\hline 33. Express feelings & 1.81 & 0.75 & 1.62 & 0.97 & -0.85 \\
\hline 34. Be honest with others & 1.90 & 0.83 & 1.57 & 1.08 & -1.05 \\
\hline 35. Delegate responsibility & 1.67 & 0.58 & 1.05 & 0.92 & $-2.65^{*}$ \\
\hline
\end{tabular}

Note. ${ }^{*}$ Indicates t-Value significance at 0.05 level of confidence $(\mathrm{DF}=20)$.

Rating Scale: $0=$ No Gain; $1=$ Slight Gain; $2=$ Moderate Gain; $3=$ A Lot of Gain. 


\section{Participant's Knowledge of Host Culture}

The data in Table 4 depict the representatives' basic knowledge of their host culture (before and after the exchange). Fifteen general questions about one's host country were asked and the responses were counted either correct or incorrect, on a one point each basis. The respondents showed a significant increase in knowledge regarding their host culture after returning to the U.S. Before the exchange the mean was 4.90 questions answered correctly and after the exchange the mean increased to 10.62 correct answers. The high standard deviations imply a large variation in the respondents' scores. 
Table 4.

Comparison of Participants Knowledge of Host Culture Before and After the International Exchange.

\begin{tabular}{lccc}
\hline \multicolumn{1}{c}{ Variable } & $\underline{\mathrm{M}}$ & $\underline{\mathrm{SD}}$ & $\underline{\mathrm{t}-\text { Value }}$ \\
\hline $\begin{array}{l}\text { Correct Knowledge } \\
\text { Responses (Before) }\end{array}$ & 4.90 & 2.53 & \\
$\begin{array}{l}\text { Correct Knowledge } \\
\text { Responses (After) }\end{array}$ & 10.62 & & $9.68^{*}$ \\
\hline
\end{tabular}

Note. ${ }^{*}$ Indicates t-Value significance at 0.05 level of confidence $(\mathrm{DF}=20)$. Results based on 15 Questions. 


\section{CHAPTER V}

\section{SUMMARY, CONCLUSIONS, AND RECOMMENDATIONS}

\section{Summary}

The purpose of this study was to examine the extent to which the International 4-H Program achieved its objectives with regard to the six-month U.S. International 4-H Youth Exchange (IFYE) program. This was achieved by administering a pre- and postevaluation to the 1999 U.S. IFYE representatives before and after their international exchange experience. The IFYE program which is managed by CD International in cooperation with the Cooperative Extension Service, provides the opportunity for 4-H youth to travel abroad and live with host families from four weeks to six months with the goal of developing cross-culture attitudes, skills, knowledge and understanding. The intent of this study was to determine if the objectives set by the program were actually being accomplished by the IFYE representatives.

The population in the study was the 1999 International 4-H Youth Exchange Representatives from 13 states across the United States. Twenty-one participants were chosen during the winter of 1999 to serve as representatives to a foreign country for six months during the summer and fall of 1999. All of the participants in the IFYE program met at the National 4-H Center in Chevy Chase, MD at the end of June 1999 for several days of orientation. During this time the participants completed the pre-evaluation survey questionnaire. After the exchange was completed all of the participants assembled again at the National 4-H Center for several days during the middle of December 1999. During this time the post-evaluation survey was completed by all of the exchange representatives. All 
21 of the participants in the program completed both the pre- and post-evaluation, therefore, no sampling of the population was needed.

A census survey research method was used to collect the data from the 1999 IFYE representatives. The participants were surveyed while attending the exchange program orientation in June and the program debriefing in December. The researcher personally administered the evaluations during the program orientation and debriefing.

The data collection instrument which provided data to meet the objectives of the study, was developed based upon information gathered from related literature. The survey instrument was divided into four sections. Section I of the IFYE evaluation contained statements which requested the representatives' attitudes and perceptions based on a fourpoint Likert-type scale. Section II of the evaluation involved rating ones level of development regarding Life Skills and was also based on a four-point Likert-type scale. Section III involved knowledge questions about the participants' host culture and Section IV requested demographic information.

The population consisted of 7 males and 14 females with an average age of 21 years. Approximately half of the representatives were from the North Central region of the US. Six originated from the Western region, and four came from the Northeast. The Southern region had no participants in the 1999 IFYE exchange program.

Ninety-five percent of the population had been in 4-H for nine or more years. All 21 participants had completed high school, and $48 \%$ had earned their bachelor's degree. One IFYE had obtained their Master's degree, and two had earned their associate degree. Approximately $81 \%$ of the representatives had traveled outside of the U.S. previous to this exchange. The majority had traveled 1-15 days outside of the U.S., three however, had traveled for more than 60 days outside of the U.S. Less than one third of the 
participants and/or their families had hosted an IFYE previously. All 21 of the representatives replied they would recommend the IFYE exchange program to other 4-H members.

The representatives indicated that $27 \%$ of their attitudes and/or perceptions relating to a different culture changed during their exchange stay. The largest growth occurred in their perception of their own knowledge of their host country. The greatest attitudinal change indicated that after the exchange more of the representatives believed that the citizens' of their host country wished they lived in the U.S. The IFYE participants also implied their change in attitude towards the need to learn a foreign language. After the exchange participants indicated they feel it is less important to learn a foreign language because most people speak English. They also responded that a program such as IFYE does help develop positive communication between cultures.

After the exchange the participants' indicated that they believed religion was less of an important part of their host culture than they had originally thought. The postevaluations also suggest that the participants believe that the U.S. is the best country to live in and that the citizens of their host country view Americans more positively than they had first thought. After the international exchange experience all 21 of the participants "Strongly Agreed" that it was important to know about world issues.

The participants indicated more than "Moderate Gain" in 57\% of the 35 Life Skills evaluated. Interestingly, the representatives implied their level of Life Skill growth was less than they had anticipated. Seventy-seven percent of the Life Skills statements had lower means after the exchange. Of the six life skills that significantly differed in before and after responses, the only one indicating more development than expected was the ability to selecting alternatives. 
The participant's level of cultural knowledge significantly increased after their IFYE exchange. During the pre-evaluation only $33 \%$ of the questions related to host culture were answered correctly. After the exchange, $71 \%$ of the responses were correct. The representatives more than doubled their knowledge level pertaining to their host countries.

Conclusions

Within the limitations of this study and based upon the findings, the following conclusions are made:

1. Those most likely to participate in the IFYE program are 21-year old females who have completed four years of college from the North Central region of the US and who have previously traveled outside of the United States and have been in 4- $\mathrm{H}$ for nine or more years.

2. The IFYE representatives' positive cross-cultural attitudes and perceptions existed before their 1999 six-month 4-H international exchange experience. The experience, however, results in greater appreciation for the United States, strengthens awareness of world issues, improves communication skills, and overcomes misperceptions held about the host country.

3. While life skills of the IFYE representatives are positively influenced by the international experience, they are not enhanced to the extent expected prior to program participation.

4. Knowledge of the country greatly improves when one is submerged directly into the foreign culture.

5. World issues become increasingly important after one has visited/lived in another country. 


\section{$\underline{\text { Recommendations }}$}

Based upon the findings in this research, the researcher's experiences, and the review of literature, the following are recommendations for the IFYE program and future research studies:

1. This study should be modified and a longitudinal study on the 1999 IFYE representatives should conducted in order to determine if and how the international exchange continued to influence their cross-cultural attitudes, skills, and knowledge throughout their lives.

2. This study should be replicated in its complete or modified form using the four-week and three-month IFYE populations.

3. The IFYE program should be studied using qualitative methodologies in order to more accurately assess program performance.

4. As cultures around the world become more closely linked due to technological advancements, it is critical that youth be strongly encouraged and supported to participate in exchange programs such as IFYE.

5. The objectives of the 4-H International Program should be clarified in order to make effective evaluations more feasible. 


\section{REFERENCES}

Ary, D., Jacob, L. C., \& Razavieh, A. (1996). Introduction to Research in $\underline{\text { Education. }}$ ( $5^{\text {th }}$ ed.). Ft. Worth: Holt, Rinehart and Winston, Inc.

Boyd, A. M. (1971). An Analysis of the Role of the International Farm Youth Exchange Program in Cross-Cultural Communication. (Masters Thesis, University of Washington, 1971.) ERIC Document Reproduction Service No. ED066633.

Chapman-Novakoski, K., Boeckner, L. S., Canton, R., Clark, C.D., Keim, K., Britten, P., \& McClelland, J. (1997). Evaluating Evaluation-What We've Learned Journal of Extension.35 (1).

Dormody, T., \& Seevers, B. (1994). Predicting youth leadership life skills among FFA members in Arizona, Colorado, and New Mexico. Journal of Agricultural Education $\underline{35}(2), 65-71$.

Etling, A. (1994). Creating a Stronger Model for International Youth Exchange: A Case Study. Journal of International Agricultural and Extension Education.1 (2) 70-79.

Fitz-Gibbon, C. \& Morris, L. (1987). How to Design a Program Evaluation. Newbury Park, CA: Sage Publications.

Hansel, B. G. (1987). The Impact of a Sojourn Abroad. (Doctoral Dissertation, Syracuse University,1985). UMI Dissertation Information Service. Ann Arbor, Michigan.

Hansel, B. G. (1984). Literature Review: Studies of the Impact of a TravelAbroad Experience. (Research Report No. 28) New York, NY: AFS International/Intercultural Programs, Inc. Research Dept. 
Gobeli, V. (1998). National 4-H Youth Development Global Education Design

Team Report. Washington, D.C.: CSREES International Programs Report.

Kilby, E. (1992). Towards a Better Understanding of How to Conduct and

Evaluate Educational Exchanges. Canada, University of Victoria.

Patton, M. (1982). Practical Evaluation. Newbury Park, CA: Sage Publications.

Seevers B., Dormody, T. \& Clason, D. (1995). Developing a scale to research and evaluate youth leadership life skills development. Journal of Agricultural Education. 36 (2), 28-35.

Seevers, B., Graham, D., Gamon, J. \& Conklin, N. (1997). Education Through Cooperative Extension. New York: Delmar Publishers.

Stitsworth, M. \& Sugiyama, Y. (1990). International Youth Exchanges: Measuring Their Impact on Attitudes. Paper presented at the $16^{\text {th }}$ Congress of the International Society for Intercultural Education, Training, and Research, Kilkenny, Republic of Ireland.

Tritz, J. \& Martin, R. (1997). The Collegiate International Experience: Criteria for

Success. Association for International Agricultural and Extension Education 1997 Conference Paper. Arlington, Virginia.

Report of the 4-H International Task Force (1985). Purdue University Cooperative Extension Service. (Joint P).

Wingenbach, G. \& Kahler A. (1997). Self-Perceived Youth Leadership and Life Skills of Iowa FFA Members. Journal of Agricultural Education. 39 (2), 18-27. 
APPENDICES 


\section{APPENDIX A}

Cover Letter to 1999 Six Month IFYE Representatives 
December 11, 1999

Dear International 4-H Youth Exchange Participant:

Congratulations on being selected as an International 4-H Youth Exchange representative! I am conducting research for partial fulfillment of the requirements for a Master's of Science in Agricultural and Environmental Education. The purpose of my study is to determine the extent to which the International 4-H Youth Exchange Program achieves its objectives involving cross-cultural attitudes, skills, and knowledge. The following sections of this evaluation will give you the opportunity to tell us about yourself and some of your attitudes, skills, and knowledge about your host country.

Please read the directions for each section carefully. Before you begin filling out the evaluation please keep in mind the following:

1. DO NOT write your name on any part of this evaluation.

2. Please answer each question honestly and as accurately as possible.

3. Your answers will be kept strictly confidential, and only group responses will be reported.

Participation in this survey is voluntary, and you do not have to answer every question. If you decide not to complete this survey, that is your right and it shall be respected. Thank you for your time and contribution to improving the IFYE program.

Sincerely,

Mary E. Williams

Graduate Student

Agricultural and Environmental Education 


\section{APPENDICES B}

The International 4-H Youth Exchange (IFYE) Evaluation 


\section{PART I: Attitudes}

What are your current cross-cultural attitudes? Please CIRCLE the rating that best describes your level of agreement or disagreement for each statement below.

\section{Strongly Disagree $=$ SD $\quad$ Disagree $=\mathrm{D} \quad$ Agree $=$ A $\quad$ Strongly Agree $=$ SA}

\begin{tabular}{|c|c|c|c|c|}
\hline & SD & $\mathrm{D}$ & A & SA \\
\hline 1. I am very knowledgeable about the culture of my host country & 1 & 2 & 3 & \\
\hline 2. People in my host country are supportive of their government. & 1 & 2 & 3 & 4 \\
\hline $\begin{array}{l}\text { 3. The eating habits of the people in my host country are similar to the } \\
\text { eating habits of US. citizens. }\end{array}$ & 1 & 2 & 3 & 4 \\
\hline $\begin{array}{l}\text { 4. The citizens from my host country have strong family values (i.e. the } \\
\text { nuclear family unit is important). }\end{array}$ & 1 & 2 & 3 & 4 \\
\hline 5. People in my host country believe education is important. & 1 & 2 & 3 & 4 \\
\hline 6. American food is better than food available in my host country. & 1 & 2 & 3 & 4 \\
\hline $\begin{array}{l}\text { 7. The education system in my host country is } \mathrm{s} \\
\text { education system. }\end{array}$ & 1 & 2 & 3 & 4 \\
\hline 8. It is important to know about world issues. & 1 & 2 & 3 & 4 \\
\hline try's culture. & 1 & 2 & 3 & 4 \\
\hline $\begin{array}{l}\text { government system is better than the type of government in } \\
\text { country. }\end{array}$ & 1 & 2 & 3 & 4 \\
\hline $\begin{array}{l}\text { is are superior in knowledge compared to the citizens from } \\
\text { intry. }\end{array}$ & 1 & 2 & 3 & 4 \\
\hline $\begin{array}{l}\text { 12. The government system in the United States is better than all other } \\
\text { forms of government. }\end{array}$ & 1 & 2 & 3 & 4 \\
\hline $\begin{array}{l}\text { e people from my host country are similar to the } \\
\text { itizens. }\end{array}$ & 1 & 2 & 3 & 4 \\
\hline in the United States is superior to all other forms & 1 & 2 & 3 & 4 \\
\hline 15. The holidays in my host country are similar to U. S. holidays. & 1 & 2 & 3 & 4 \\
\hline 16. Per & 1 & 2 & 3 & 4 \\
\hline 17. The & 1 & 2 & 3 & 4 \\
\hline 18. The & 1 & 2 & 3 & 4 \\
\hline 19. Cou & 1 & 2 & 3 & 4 \\
\hline $\begin{array}{l}\text { 20. The media coverage of world issues is } \\
\text { cultures. }\end{array}$ & 1 & 2 & 3 & 4 \\
\hline 21. The & 1 & 2 & 3 & 4 \\
\hline $\begin{array}{l}\text { lould take care of its own problems } \\
\text { ies. }\end{array}$ & 1 & 2 & 3 & 4 \\
\hline 23. It is & 1 & 2 & 3 & 4 \\
\hline 24. It & 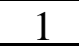 & 2 & 3 & 4 \\
\hline 25. Th & 1 & 2 & 3 & 4 \\
\hline 26. $\mathrm{Ar}$ & 1 & 2 & 3 & 4 \\
\hline $\begin{array}{l}\text { 27. All US college aged citizens should be required to participate in an } \\
\text { international exchange program. }\end{array}$ & 1 & 2 & 3 & 4 \\
\hline 28. Citiz & 1 & 2 & 3 & 4 \\
\hline $\begin{array}{l}\text { 29. An international youth exchange program such as IFYE helps develop } \\
\text { positive communication skills. }\end{array}$ & 1 & 2 & 3 & 4 \\
\hline 30. People from other cultures are not very different $\mathrm{fr}$ & 1 & 2 & 3 & 4 \\
\hline
\end{tabular}




\section{PART II: Skills}

What Leadership Life Skills do feel have improve because of your involvement in the IFYE program? Please evaluate each item by CIRCLING the number you feel represents your gain for each skill.

\begin{tabular}{|c|c|c|c|c|}
\hline As a result of my IFYE experience I am able to: & $\begin{array}{c}\text { No } \\
\text { Gain }\end{array}$ & $\begin{array}{c}\text { Slight } \\
\text { Gain }\end{array}$ & $\begin{array}{c}\text { Moderate } \\
\text { Gain }\end{array}$ & $\begin{array}{c}\text { A Lot } \\
\text { Of Gain }\end{array}$ \\
\hline 1. Determine needs & 0 & 1 & 2 & 3 \\
\hline 2. Have a positive self-concept & 0 & 1 & 2 & 3 \\
\hline 3. Express feelings & 0 & 1 & 2 & 3 \\
\hline 4. Set goals & 0 & 1 & 2 & 3 \\
\hline 5. Be honest with others & 0 & 1 & 2 & 3 \\
\hline 6. Use information to solve problems & 0 & 1 & 2 & 3 \\
\hline 7. Delegate responsibility & 0 & 1 & 2 & 3 \\
\hline 8. Set priorities & 0 & 1 & 2 & 3 \\
\hline 9. Be sensitive to others & 0 & 1 & 2 & 3 \\
\hline 10. Be open-minded & 0 & 1 & 2 & 3 \\
\hline 11. Consider the needs of others & 0 & 1 & 2 & 3 \\
\hline 12. Show a responsible attitude & 0 & 1 & 2 & 3 \\
\hline 13. Have a friendly personality & 0 & 1 & 2 & 3 \\
\hline 14. Consider input from all group members & 0 & 1 & 2 & 3 \\
\hline 15. Listen effectively & 0 & 1 & 2 & 3 \\
\hline 16. Select alternatives & 0 & 1 & 2 & 3 \\
\hline 17. Recognize the worth of others & 0 & 1 & 2 & 3 \\
\hline 18. Create an atmosphere of acceptance in groups & 0 & 1 & 2 & 3 \\
\hline 19. Consider alternatives & 0 & 1 & 2 & 3 \\
\hline 20. Solve problems & 0 & 1 & 2 & 3 \\
\hline 21. Handle mistakes & 0 & 1 & 2 & 3 \\
\hline 22. Be tactful & 0 & 1 & 2 & 3 \\
\hline 23. Be flexible & 0 & 1 & 2 & 3 \\
\hline 24. Get along with others & 0 & 1 & 2 & 3 \\
\hline 25. Improve foreign language skill & 0 & 1 & 2 & 3 \\
\hline 26. Clarify my values & 0 & 1 & 2 & 3 \\
\hline 27. Be respectful & 0 & 1 & 2 & 3 \\
\hline 28. Be open to change & 0 & 1 & 2 & 3 \\
\hline 29. Improve ability to read a foreign language & 0 & 1 & 2 & 3 \\
\hline 30. Be patient & 0 & 1 & 2 & 3 \\
\hline 31. Improve self-esteem & 0 & 1 & 2 & 3 \\
\hline 32. Use rational thinking & 0 & 1 & 2 & 3 \\
\hline 33. Have good manners & 0 & 1 & 2 & 3 \\
\hline 34. Value others opinions & 0 & 1 & 2 & 3 \\
\hline 35. Trust other people & 0 & 1 & 2 & 3 \\
\hline
\end{tabular}




\section{PART III: Knowledge of your Host Country}

At this time, what do you know about your host country? Please answer only those questions you know for certain regarding your host country. If you do not know the answer leave it blank. My host country is

1. The capital city is

2. The approximate population is

3. The primary language spoken is

4. The main form of government is

5. The current leader is

6. The top three exports are

7. The top three imports are

8. The primary mode of transportation is

9. The average household income is

10. The primary vegetables eaten are

11. The main source of protein in the diet is

12. The percent of the population that live in rural areas is

13. The percent of the population that live in urban areas is

14. The average education level is

15. The countries which border it are

\section{PART IV: Demographics}

Please Fill in or Checkmark $(\sqrt{ })$ the response that best represents you.

1. Home State:

2. Age:

3. Gender: Male Female

4. Years in 4-H:

5. Martial Status: __ Single _ Married

Other

6. Highest Level of Education Completed:
H.S. Degree
A.A. Degree
B.S. Degree

M.S. Degree

Other

7. Have you traveled outside of the United States before? Yes No

8. If YES to \#7, for how many days?
$1-15$
16-30 $31-45$ $46-60$ More Than 60 Days

9. Have you or your family hosted an IFYE participant before?

$$
\text { Yes _ No }
$$

10. Would you recommend the IFYE program to other 4-H members? Yes No 


\section{APPENDIX C}

National Association of Extension 4-H Agents U.S. Regions 


\section{National Association of Extension 4-H Agents U. S. Regions}

North East:

Connecticut, Delaware, Maine, Maryland, Massachusetts, New Hampshire, New Jersey, New York, Pennsylvania, Rhode Island, Vermont, and West Virginia.

North Central:

Illinois, Indiana, Iowa, Kansas, Michigan, Minnesota, Missouri, Nebraska, North Dakota, South Dakota, Ohio, and Wisconsin.

South:

Alabama, Arkansas, Florida, Georgia, Kentucky, Louisiana, Mississippi, North Carolina, South Carolina, Oklahoma, Tennessee, Texas, and Virginia.

$\underline{\text { West: }}$

Alaska, Arizona, California, Colorado, Hawaii, Idaho, Montana, New Mexico, Nevada, Oregon, Utah, Washington, and Wyoming. 
VITA 


\section{VITA}

May 1, 1974

May 1992

August - December 1994

May 1996

June 1996 - May 1997

August 1998 - Present
Born: Hardy County, West Virginia

High School Graduation

Moorefield High School

Study Abroad Semester

The American International University

London, England

Bachelors of Arts Degree in

Psychology and Sociology

West Virginia Wesleyan College

Buckhannon, West Virginia

West Virginia International 4-H Youth

Exchange (IFYE) Representative to Sweden

Graduate Student

Agricultural and Environmental Education

West Virginia University

Morgantown, WV 